\title{
Competency Model for microentrepreneurs in depressed environments
}

\begin{abstract}
Microentrepreneurs who have their businesses located in depressed regions are generally unaware of their basic competencies, especially their application and the benefits that are obtained when these are linked to the development of business management. Knowing the skills and abilities of the people, directs the activities in an organized and planned way. Under this premise, a competency model is proposed for microentrepreneurs who carry out their activities in depressed environments. Based on a documentary research, the competences in dimensions are identified and grouped; Likewise, the importance of the model is determined with the support of a panel of experts linked to the microenterprise sector. The competences proposed are oriented to an easy and correct application, and distributed in the areas of action in which microentrepreneurs develop their activities. It establishes twenty-seven (27) competencies that determine microentrepreneurs competences in depressed environments, grouped in four (4) dimensions: Self-management, Motivation, Empathy and Social Skills. The proposed model seeks to strengthen administrative management, helps to increase business performance, and personal and professional training of microentrepreneurs.
\end{abstract}

Key-Words: competences, competence model, microentrepreneurs, microenterprises, depressed environments, competencies, skills.

CLASSIFICATION JEL: $\quad$ M13 - J24 - L26

\section{Introduction}

The study of people's competences is an issue that has recently been at the center of research activity in the field of business economics and human resource management. In a time of globalization and dynamic technological changes, the strategic management of competences at all levels of personnel becomes a highly relevant task for the management of human resources (Deciusa \& Schaper a, 2017). It is therefore vital for organizations to assess and continually improve the competence of the workforce to meet the challenge of today's competitive environment, as these depend on the skills of their staff as their main asset for success (Worlikar \& Aggrawal, 2017). Today, organizations are talking in terms of competence, so that competence models have become an inseparable part of human resource management and have been widely used as a mean to increase personal and organizational efficiency (Singh \& Srivastava, 2014). 
Strengthening the competences of human capital that seeks to improve entrepreneurial training is one of the elements that can most directly be included in public policies, being this one of the aspects that has a major effect on the formalization of the microentrepreneur (Aguilar-Barceló, Texis -Flores \& Ramírez-Angulo, 2011); it is also known that well-formed human capital is key to fostering dynamic entrepreneurship in developing economies (Cancino, Coronado \& Farias, 2012).

The impact of people's skills on microentrepreneurs (or individual entrepreneur, ie a natural person who exercises in their own name or through a representative, an economic, business or professional activity) is more relevant (Fernández \& Guadaño, 2005). Managerial competence is the ability of managers and leaders to direct workflows and define results clearly; identifying the competence requirement to achieve an occupational field is a critical process in management, where the task of identifying qualities defines the efficiency of managers (Manxhari, Veliu \& Jashari, 2017).

Microenterprise represents an important part of the economic structure in most countries (Mungaray \& Ramírez, 2007). Although, literature suggests that these companies face institutional, market, productive, financial and human capital constraints (RamirezUrquidy \& Mungaray 2016); many come from taking advantage of the gaps left by the medium and large companies to take advantage of a small business opportunity because of their size and flexibility (Neef, 1998).

Although there is no determinant factor in the survival probability of microenterprises, the combination of certain conditions may favor it (Texis, Ramírez \& Aguilar, 2016); in the empirical field, the relationship between organizational learning and microenterprise performance has been approached from different approaches (Mungaray, Feitó \& Texis, 2016). Authors such as Beato \& Poli (2008) point out that a typical characteristic of this sector is the low specialization of its managers, because they are forced to perform administrative, financial, commercial and technical functions.

In general, small and medium-sized enterprises (SMEs), where many authors include microenterprises, have been given a lot of attention in recent entrepreneurial research because of their vital contributions to the economy of each country; their presence is very important, especially in developing countries, where they help economic growth (Tehseen \& Ramayah, 2015). SMEs have always been a major contributor to a country's economic prosperity; in the era of globalization, companies have been forced to go beyond the borders to sustain their competitive advantage to succeed, so internationalization has become a way to continue to increase their performance and this movement has open doors to the positioning of SMEs (Zalina, Firdaus \& Azman, 2016).

On the other hand, we find the depressed environments or zones, which according to the LID Dictionary of Business and Economy of Madrid (Elosúa, 1999) are defined as areas or regions of a country that are distinguished from the others by their lower degree of industrialization. These environments can be determined by the levels of poverty and income inequality (World Bank, 1998), indicators that have been considered in this study, as will be seen later. It is also worth considering other factors that are present in depressed environments, such as excessive rural exodus, which is oriented towards factories in need of low-skilled labor and often in conditions of misery, which allows, in exchange for very little they are offered the hope of improving survival conditions (Urrego, 1998). 
In the case of Ecuador, a country made up of 24 provinces and a total of 221 cantons $^{1}$, 118 cantons were declared by the Sectorial Council of Production as depressed areas, out of a total of 221. It is observed that in the specific case of region 5, which is made up of 46 cantons, 15 of which belong to the group of 89 classified as depressed, implying that $31 \%$ of the cantons in this region are economically depressed areas. For the determination of depressed areas, a methodology approved by the Sectorial Council of Production, which combines criteria of social vulnerability with those of productive development capacities of each canton (Coordinating Ministry of Production, Employment and Competitiveness, 2017) is considered.

Official statistics from Ecuador (INEC, 2016) show that there is a high degree of external dependence on the supply of goods, especially machinery and capital goods, as well as consumer goods such as food products (Bezpalov, Lochan \& Sorokina, 2016). Therefore, it is essential in these sectors to motivate the creation of own and local businesses directed to the consumption of national goods, which gradually reduce the level of dependence. In this premise it is essential to recognize the importance of the knowledge of human capital in business development and in strengthening entrepreneurship, which values a better knowledge of the main competencies that microentrepreneurs should possess to develop the exposed role.

In this context, the main purpose of this study is to adapt to Ecuador's case a model of labor and personal skills for the microenterprise sector in depressed environments. Methodologically, a documentary research was carried out, specifically a theoretical development study based on a critical review of the state of knowledge, which allowed the identification of a model that would be adapted to the Ecuadorian context of microenterprises in depressed environments.

The competence model was adapted based on the models by Boyatzis, Goleman \& Rhee (2000) and the Hay Group McClelland Center for Research and Innovation (2005). Likewise, the inventory of competencies was refined from the judgment of a panel of experts. Additionally, for the study of the impact of the application of the model in the proposed environment, a pool of questions formulated based on the documentary review was presented to the panel of experts.

The rest of the paper is organized as follows: the various dimensions of the theoretical framework are presented, which include aspects of depressed environments, the microenterprise sector and competence models; the methodology of the research is described, the results are presented and discussed; and, finally, the conclusions are presented.

\section{Theoretical framework}

\section{Depressed environments or areas (in general and Ecuador)}

\section{Characterization: orientations, factors and phenomena}

According to Mel'nikova (2015) there are basically two orientations for the study of depressed areas: the one professed by the school of the World Bank (2009) and the one taught by the School of the Organization for Economic Co-operation and Development (OECD, 2009). The World Bank points to a neutral space approach that excludes

\footnotetext{
${ }^{1}$ The canton, the second-level administrative division in Ecuador, subdivides territorially a municipality, province, department or other type of district.
} 
interventionist measures, and presents a marked influence of Williamson's (1965) theory on regional disparities. Advocates of this school believe that the problems of regional economies are associated with inefficient spatial distribution and the insufficient mobility of productive factors between regions. Therefore, it recommends eliminating all regulatory restrictions that could distort market signals and limit mobility, ruling out measures to support the economies of depressed regions.

On the other hand, the OECD school promotes a more active approach that often suggests the use of various measures to stimulate growth in different regions. The OECD (2009) pointed to a paradigm shift in regional policy, which meant a transition towards a policy of compensation for business and the population to identify and stimulate the growth potential of depressed regions. It is considered to support development through a comprehensive regional policy involving all levels of government and functional economic sectors, within the framework of integrated development projects to develop the underutilized potential of all regions to improve their competitiveness. The objective is to develop the tangible and intangible capital of the regions, including social capital, labor markets, business climate and social networks (OECD, 2009).

The review of literature also allows us to observe some phenomena characteristic of depressed environments (Sachs \& Warner, 2001, Williamson, 1969, Capello, 2006, Gohmann \& Fernández, 2014). On the one hand is the relationship between unemployment and microenterprise. It is observed that as unemployment increases, some of the people with few alternatives to work can choose to start their own business, thus increasing microenterprise ratios. In parallel, if an increase in unemployment is the result of a depressed economy, it lowers the demand for products and services, causing the closure of microenterprises. To the extent that microenterprises can survive, they could increase employment, which may be beneficial in the long run in terms of reducing unemployment and raising the level of income (Gohmann \& Fernández, 2014).

Another phenomenon that occurs in depressed environments is the excessive rural exodus, which is oriented towards factories in need of unskilled labor and often in misery conditions (Urrego, 1998).

Depressed environments of the Ecuador: Indicators and zone determination

In the case of Ecuador geographical factors greatly influence in the development process and there is a significant migration from rural to large cities, resulting in overcrowding in cities of destination that hinders the generation of jobs and that leads to disorganized creation of microenterprises.

It should be noted that in Ecuador, imported products are concentrated in raw materials, consumer goods, fuels / lubricants and capital goods, as shown in Table 1. Since the dependence of these products is high, it is advisable for the country to encourage the motivation to undertake in businesses that produce this type of products and services. 
Table 1

Imports per use compared to exports

\begin{tabular}{ccccccccc}
\hline \multicolumn{7}{c}{ FOB IMPORTS BY USE OR ECONOMIC DESTINATION } \\
\hline YEARS & $\begin{array}{c}\text { CONSUMER } \\
\text { GOODS }\end{array}$ & $\begin{array}{c}\text { FUELS AND } \\
\text { LUBRICANTS }\end{array}$ & $\begin{array}{c}\text { RAW } \\
\text { MATERIAL }\end{array}$ & $\begin{array}{c}\text { CAPITAL } \\
\text { GOODS }\end{array}$ & $\begin{array}{c}\text { MISCELLA } \\
\text { NEUS }\end{array}$ & $\begin{array}{c}\text { TOTAL } \\
\text { IMPORTS }\end{array}$ & $\begin{array}{c}\text { TOTAL } \\
\text { EXPORTS }\end{array}$ & $\begin{array}{c}\text { BALANCE } \\
\text { OF } \\
\text { TRADE }\end{array}$ \\
\hline 2013 & 5,185 & 5,927 & 7,823 & 6,767 & 61 & 25,763 & 28,033 & $-2,270$ \\
2014 & 5,187 & 6,417 & 8,076 & 6,685 & 56 & 26,421 & 28,423 & $-2,002$ \\
2015 & 4,219 & 3,950 & 6,878 & 5,342 & 58 & 20,447 & 23,634 & $-3,187$ \\
2016 & 3,370 & 2,490 & 5,688 & 3,941 & 56 & 15,545 & 15,072 & 474 \\
\hline
\end{tabular}

Source: Central Bank of Ecuador

The National Institute of Statistics and Censuses, as the official provider of statistics for Ecuador, presents various indicators related to poverty (INEC, 2016). As shown in Figure 1 , the poverty rate by income is reduced by 13.8 percentage points (from $36.7 \%$ to $22.9 \%$ ) in the 2007-2016 period, that is, about 1.4 million people leaving poverty condition of a population of approximately 5.22 million. Likewise, the rate of extreme poverty was reduced by almost half ( 7.8 percentage points) in the same period, going from 16.5 to 8.7 percentage points.

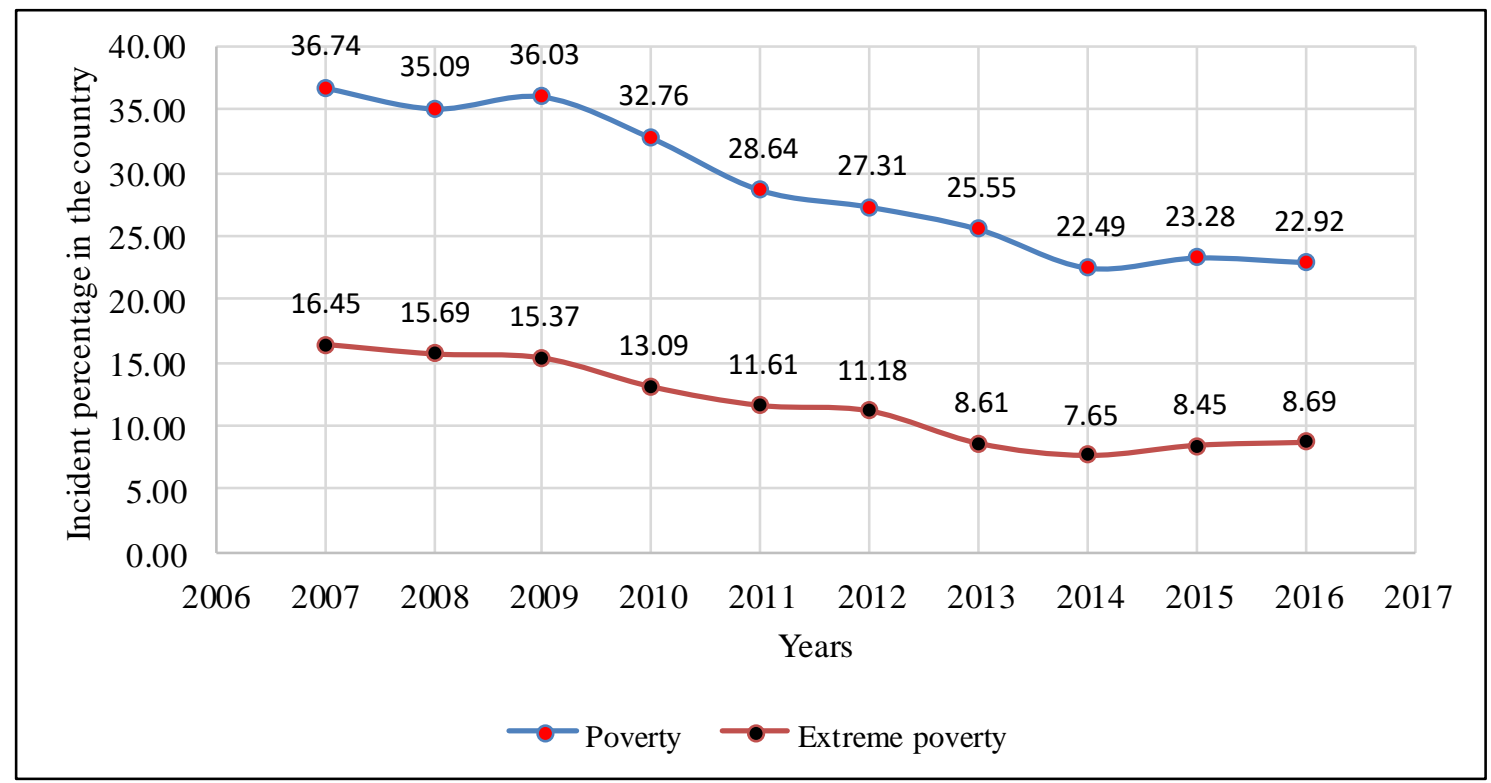

Figure 1. Evolution of poverty and extreme poverty in Ecuador

Source: Ecuadorian Institute of Statistics and Censuses of Ecuador

In terms of employment rates and as shown in Figure 2, in the period from 2007 to 2016 the unemployment rate remained stable, falling from 43.2 to 41.2 percentage points, with a significant decrease of 5.3 points in relation to the same month of 2015; the national underemployment showed a similar behavior but the reverse; and the unemployment rate rose slightly from 5 to 5.2 percentage points. 


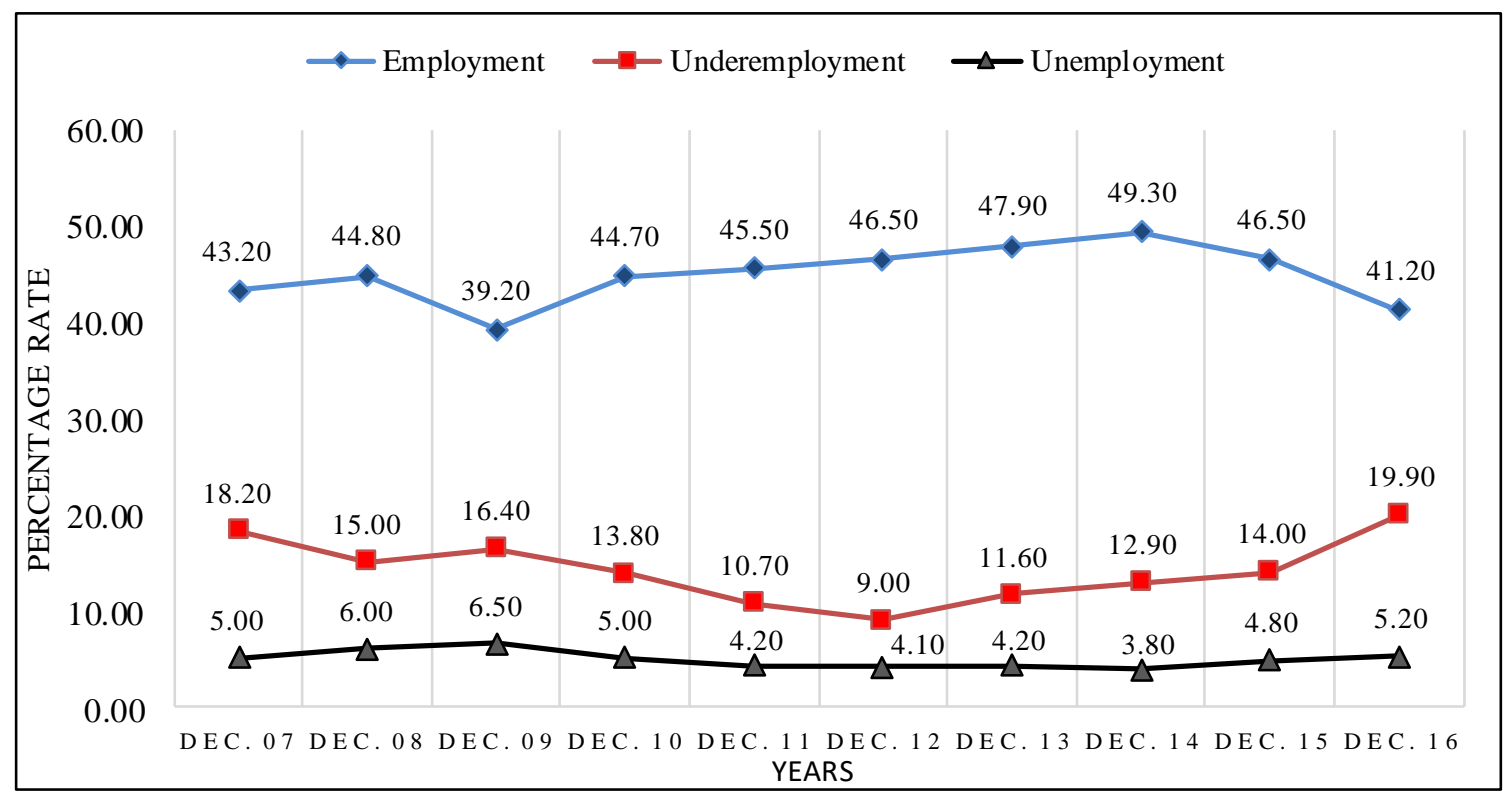

Figure 2. Evolution of rates of adequate employment, underemployment and unemployment Source: Ecuadorian Institute of Statistics and Censuses of Ecuador

In terms of income inequality, the Gini coefficient shown in Figure 3 shows, for the same period 2007-2016, a decrease of 0.08 percentage points in line with a slight decrease in inequalities.

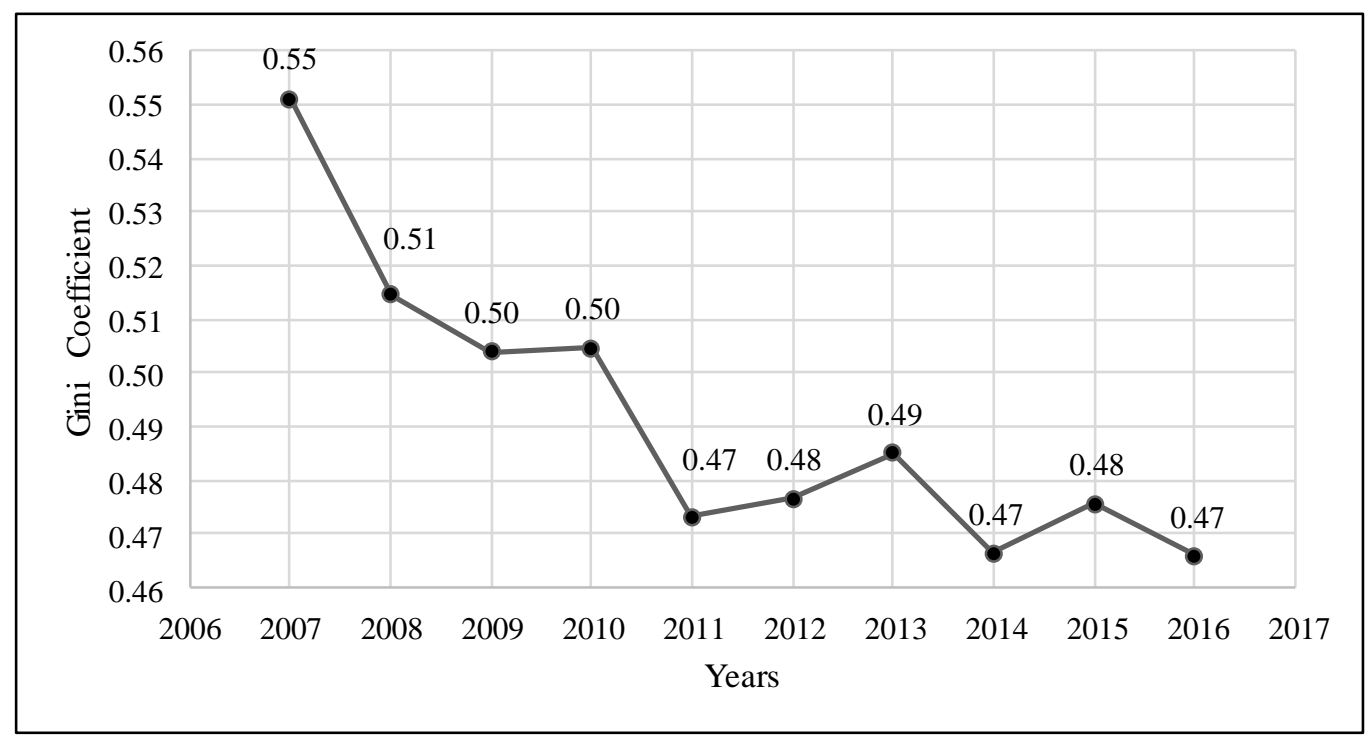

Figure 3. Evolution of the Gini Coefficient (National Inequality)

Source: Ecuadorian Institute of Statistics and Censuses of Ecuador

The National Government of Ecuador, through its territorial prioritization policy, aims to boost all regions of the country, and especially emphasizes the productive transformation of the most vulnerable areas (Coordinating Ministry of Production, Employment and Competitiveness, 2017). For the determination of depressed areas, it is considered an approved methodology that combines criteria of social vulnerability with those of productive development capacities of each canton (Sectoral Council of Production, 2017), considering two strategic axes: the social and the economic ones. The social axis includes 
variables related to poverty and unsatisfied basic needs. In the economic axis, the economic structure of each canton is analyzed, using as indicators the percentage of the Economically Active Population (EAP) and the credit granted in each canton. These two axes allow us to know the most vulnerable cantons of the country, from a socio-economic perspective.

For the application of the referred methodology, the 24 provinces (221 cantons) constituting Ecuador were grouped into 10 administrative planning regions, which are shown in Table 2. In the identification of these regions, geographical proximity, and cultural and economic similarities (SENPLADES, RO290, 2012) were considered.

Table 2

Administrative Planning Regions of Ecuador

\begin{tabular}{cll}
\hline Region & Number of provinces/cantons & Name of provinces/cantons \\
\hline 1 & 4 Provinces & Carchi, Esmeraldas, Imbabura, Sucumbios \\
\hline 2 & 3 Provinces & Napo, Pichincha, Orellana \\
\hline 3 & 4 Provinces & Chimborazo, Cotopaxi, Pastaza, Tungurahua \\
\hline 4 & 2 Provinces & Manabi, Santo Domingo \\
\hline 5 & 4 Provinces & Bolívar, Guayas, Los Rios, Santa Elena \\
\hline 6 & 3 Provinces & Azuay, Cañar, Morona Santiago \\
\hline 7 & 3 Provinces & El Oro, Loja, Zamora Chinchipe \\
\hline 8 & 1 Canton & Metropolitan District of Guayaquil \\
\hline 9 & 1 Canton & Metropolitan District of Quito \\
\hline 10 & 1 Province & Galapagos Special Regimen \\
\hline
\end{tabular}

Source: National Secretariat for Planning and Development (SENPLADES, 2012)

At the national level, 118 cantons were declared as depressed areas out of a total of 221 , as shown in Table 3 .

Table 3

Percentage ratio: depressed cantons and total cantons provinces of Ecuador

\begin{tabular}{cccc}
\hline Region & $\begin{array}{c}\text { Number of cantons } \\
\text { declared depressed }\end{array}$ & $\begin{array}{c}\text { Number of cantons of the } \\
\text { provinces that make up } \\
\text { the regions }\end{array}$ & $\begin{array}{c}\text { Percentage Ratio between } \\
\text { depressed cantons and } \\
\text { total cantons }\end{array}$ \\
\hline 1 & 22 & 27 & $81 \%$ \\
\hline 2 & 6 & 17 & $35 \%$ \\
\hline 3 & 10 & 30 & $33 \%$ \\
\hline 4 & 23 & 23 & $100 \%$ \\
\hline 5 & 15 & 48 & $31 \%$ \\
\hline 6 & 12 & 34 & $75 \%$ \\
\hline 7 & 30 & 39 & Urban Zones \\
\hline 8 & Does not Apply & Metropolitan District & Urban Zones \\
\hline 9 & Does not Apply & Metropolitan District & Special Regime \\
\hline 10 & 0 & 3 & \\
\hline Total & $\mathbf{1 1 8}$ & $\mathbf{2 2 1}$ & \\
\hline
\end{tabular}

Source: Coordinating Ministry of Production, Employment and Competitiveness, 2017

Region 5 is made up of 48 cantons, 15 of which are considered as depressed, implying that it is the fourth region with the most depressed cantons in absolute terms and the seventh according to the ratio with respect to the total cantons of the region (a $31 \%$ ). These data show that this region is suitable for studies related to depressed areas, so it was selected for the field study of this work, after considering also that it is a zone of influence of the State University of Milagro, an institution that promotes research. 


\section{The microenterprise (in general and Ecuador case)}

Microenterprises are the protagonists of a country's economic development (Hernández, 2009). A microenterprise is a small socioeconomic unit of production, commerce or service provision, whose creation does not require a lot of capital and due to its size, there is a productive and efficient use of resources (Rivero, Ávila, \& Quintana, 2016). The microentrepreneur or individual entrepreneur is a natural person who exercises in his own name, by himself or through a representative, an activity that constitutes a company, a professional activity or an economic activity (Fernández \& Guadaño, 2005).

It is identified, in the literature, that personal attention by the owner to several clients in a market delimited by an area of influence is one of the common characteristics shared by microenterprises with small and medium enterprises (Iduarte \& Zara, 2005).

The perception about the emergence of microenterprises is complex and can be approached from different dimensions, from changes in consumption patterns, variations in market demand, business restructuring of small-scale processes (Mungaray, 1997), or the emergence of microenterprises as an option for unemployment or labor independence to ensure income (Mungaray, Ramírez \& Texis, 2005).

Economic slowdowns tend to encourage the opening of microenterprises in regions less favored by main productive activity (Aguilar, Mungaray \& Ramírez, 2009). Other authors associate the opening of new companies (generally informal) with the country's inability to generate conditions that raise formal employment rates (Ruiz, Hernández \& Hernández-Fernaud, 2004). It has been observed that the rate of microenterprise creation is lower in periods of growth, which can be explained by the expansion of employment in the manufacturing industry (Mac-Clure, 2001).

To insist that most of the companies that operate in the developed countries are microenterprises (Hernández, 2009), being also true of Ecuador, where according to the Directory of Companies and Establishments (DIEE, 2014) - in collaboration with the National Institute of Statistics and Censuses (INEC) and the National Secretariat for Planning and Development (SENPLADES) - there were a total of 843,644 companies, of which 760,730 were microenterprises $(90.17 \%$ in percentage terms). In a complementary way, it is possible to consult in table 4 the business structure according to the size of the companies.

Table 4

Structure of Ecuadorian companies according to their size

\begin{tabular}{lcrcr}
\hline \multirow{2}{*}{ Company Size } & \multirow{2}{*}{$\begin{array}{c}\text { No. of } \\
\text { Companies }\end{array}$} & \multirow{2}{*}{ Percentage } & \multicolumn{2}{c}{ Classification Variables } \\
\cline { 5 - 5 } & & & No. of people & Annual Turnover \\
\hline Microenterprise & 760,739 & $90.17 \%$ & From 1 to 9 & Less than $\$ 100,000$ \\
Small Company & 65,135 & $7.72 \%$ & From 10 to 49 & From $\$ 100,000$ to $\$ 1,000,000$ \\
Mid-size company & 13,517 & $1.60 \%$ & From 50 to 199 & From $\$ 1,000,001$ to $\$ 5,000,000$ \\
Large company & 4,253 & $0.50 \%$ & From 200 onwards & De $\$ 5,000,000$ onwards \\
\hline \multicolumn{1}{c}{ Total } & 843,644 & $100,00 \%$ & &
\end{tabular}

Source: Directory of Companies and Establishments (INEC)

The unemployment level increased slightly in Ecuador in 2016 by 0.4 percentage points, and according to what they say (Gohmann \& Fernandez, 2014), unemployed people opt to start their own business, which results in an increase in the individual company, therefore, the percentage of participation of the microenterprise tends to increase, and therefore the unemployment rate would be reduced in the medium or long term. 
$31 \%$ of the cantons that make up Region 5 of Ecuador, are declared depressed by the Coordinating Ministry of Production, Employment and Competitiveness (2017), and $90.17 \%$ of the country's business activity, are microentrepreneurs, according to the Directory of Companies and Establishments INEC (2014). These figures show the high index of depressed areas and the importance of the microentrepreneur in the national economy, therefore support for their development becomes indispensable, and as Winterton, Delamare-Le Deist \& Stringfellow (2006) state, competences are considered specific and relevant qualities common in multiple environments and situations.

\section{Competences}

\section{$\underline{\text { Definition and generalities }}$}

The term "Competences" is sufficiently broad and ambiguous to review some of the existing definitions in the academic literature. According to McClelland (1973), a competence is "the integration of knowledge, skills, attitudes, commitments and inclinations that have outstanding people who stand out for their excellent professional and personal results." A decade later Boyatzis (1982) considers that "competences are specific personal qualities that are causally related to effective or superior performance." More current is the definition of Perrenoud (2004), who maintains that competence is the set of knowledge, skills and attitudes that must be capable of mobilizing a person, in an integrated way, to act effectively to the demands of a given context. And referring to the context, Winterton, Delamare-Le Deist \& Stringfellow (2006) consider that the competences, understood as specific qualities, are relevant and common in multiple environments and situations.

In the 1970s McClelland (1973) related competences as important predictors of employee performance success, which is confirmed in later studies such as Lucia \& Lepsinger (1999), where competencies are equated with more variable classic as the academic aptitude of the people. Since then, competence-based human resource management has become a common practice. For González and Wagenaarn (2003) competences tend to convey the meaning of what the person is "capable of" or "competent to perform," the degree of preparation, sufficiency or responsibility for certain tasks. While Montoya (2015) relates the personal competences referenced by McClelland (1973) to the development of the entrepreneurial spirit.

In general, competences have been defined as combined and integrated components of knowledge, skills and attitudes (McClelland, 1973, Boyatzis 1982, Perrenoud, 2004). As such, competencies can be learned and improved through experience, training or coaching (Man, Lau \& Chan, 2002; Volery, Mueller \& von Siemens, 2015; Wagener, Gorgievski \& Rijsdijk, 2010).

Identifying which competencies are considered important for entrepreneurs in a variety of sectors seems to be an inherent and very important part of the life and success of an entrepreneur (Stay, Durrieu \& Akhter, 2013; Latham, Jones \& Betta, 2009; Makhbul \& Hasun, 2011; Wagener et al., 2010). However, taking risks also opens the door to failures and setbacks (Baron \& Markman, 2003; Shane \& Venkataraman, 2000) and it is important that entrepreneurs have the skills to deal with these risks and possible consequences.

The skills that an entrepreneur needs to possess to run a successful business has been conceptualized both in a global and specific way. According to Mulder et al. (2007), the holistic notion of competence centers on "the ability to successfully satisfy complex 
demands in a particular context". However, there are also many authors who preferred to determine that the specific competencies that entrepreneurs need to have to succeed are more analytically and behaviorally oriented (Chwolka \& Raith, 2012, Man et al., 2002; Markman \& Baron, 2003).

\section{Competence Models}

Competence Models are effective measurement tools that help create a common language and understand what is meant by excellent performance; they translate organizational strategies, goals and values into specific behaviors (Singh \& Srivastava, 2014). They refer to a series of knowledge, skills, abilities, and other characteristics necessary for effective performance in the jobs in question (i.e., Green, 1999, Lucia \& Lepsinger, 1999, Mirabile, 1997, Rodriguez, Patel, Bright, Gregory, Gowing, 2002; Schippmann et al., 2000). It is a way of getting organizations to pay attention to job-related information and the skills applied in the management of employees (Campion et.al., 2011).

A Competence model is a valid, observable and measurable list of knowledge, skills and attributes demonstrated through behavior that results in outstanding performance in a work context (Singh \& Srivastava, 2014). The managerial competences are not fixed and must correspond to the needs of the organization; Thus, despite the variety of managerial competence models, they do not oppose to being criticized (Manxhari, Veliu \& Jashari, 2017).

Sandberg (2000) proposes a taxonomy of competence-based models based on rationalist and interpretive epistemological paradigms (see Table 5). In the rationalist approach, competences are defined from three points of view (the worker's, the job post's, and mixed), which are centered on the vision of competences as a set of attributes that workers must possess to be effective in a job. Instead, the interpretive approach is based on the meaning that the work represents for the person and their experiences.

Table 5

Approaches to the concept of competencies (Based on Sandberg, 2000)

\begin{tabular}{lll}
\hline \multicolumn{1}{c}{ Epistemology } & \multicolumn{1}{c}{ Orientation } & \multicolumn{1}{c}{ Focus } \\
\cline { 2 - 3 } Rationalist & To the worker & Characteristics of the individual \\
\cline { 2 - 3 } & To work & Inventory of activities \\
\cline { 2 - 3 } Mixed & $\begin{array}{l}\text { Characteristics of the individual and } \\
\text { Inventory of activities }\end{array}$ \\
\hline Interpretive & Meaning & $\begin{array}{l}\text { Interpretation of the person and } \\
\text { Their experience }\end{array}$ \\
\hline
\end{tabular}

Source: (Aracuna, 2010). Doctoral Thesis Competence Model for Technological Innovation

Rationalist worker-oriented models define competences as a set of individual attributes that shape people's behavior and performance. They can be of mental / intellectual / cognitive, social / emotional, attitudinal and physical / psychomotor type. Montoya (2015) relates personal competences and the development of the entrepreneurial spirit based on qualities such as communication, research, teamwork, leadership, systemic thinking, achievement orientation, perceptual amplitude, creativity and innovation, and social intelligence. According to these models, differences in performance among individuals occupying the same position are explained by differences in the attributes they possess. The main criticism of these approaches is that they generate descriptions of too general and abstract competences (Sandberg, 2000).

In the case of the work-oriented perspective, competences are also considered as a specific set of attributes, although in this case the starting point is the workplace and not 
the worker (Fine, 1988). The concept of competence is associated with the analysis of professional activities and the inventory of what needs to be done to perfectly fulfill the functions that a job entails; it is related to a series of behaviors that must be adopted to carry out the tasks and missions in a suitable way. Here the internal and external limitations, the environments and the relations that have to do with the work or occupation would fit (Boyatzis, 1982; Fogg, 1999).

Trying to avoid the criticisms made against the worker-oriented approaches and the work ones emerges a third alternative, a mixed approach, which is more comprehensive based on a combination of both approaches (Sandberg, 2000). Competences are, on the one hand, a link between the missions to be carried out and the behaviors put into practice to do so and, on the other, the individual qualities necessary to behave in a satisfactory way (Woodruffle, 1990). In this way, it is possible to generate more detailed and concrete descriptions of what constitutes a competence, and with that, to overcome, the problem of elaborating overly general descriptions of competences.

In the interpretative approach competences are seen as constituted by the meaning that the work represents for the person and his experience (DallAlba \& Sandberg, 1996). This approach shifts the starting point from the worker and the work to the experiences lived by workers at work (Sandberg, 2000).

Goleman (1998) classifies the 25 competences into five groups: self-consciousness, selfregulation, motivation, empathy and social skills, as shown in Table 6, following the rationalist approach towards the worker according to Sandberg (2000).

Table 1

Formation of competences according to groups

\begin{tabular}{cl}
\hline \multicolumn{1}{c}{ Groups } & \multicolumn{1}{c}{ Competences } \\
\hline \multirow{3}{*}{ Self-consciousness } & Emotional Awareness \\
& Fair Self-evaluation \\
& Self-confidence \\
\hline \multirow{3}{*}{ Self-regulation } & Self-control \\
& Reliability \\
& Diligence \\
& Adaptability \\
& Innovation \\
\hline \multirow{3}{*}{ Motivation } & Achievement Unit \\
& Compromise \\
& Initiative \\
& Optimism \\
\hline \multirow{2}{*}{ Empathy } & Understanding others \\
& Development of others \\
& Service Orientation \\
& Diversity of use \\
& Political Awareness \\
& Influence \\
& Communication \\
& Conflict Management \\
& Leadership \\
& Change Catalyst \\
& Strengthen ties \\
& Collaboration and \\
& cooperation \\
& Team Capabilities \\
\hline &
\end{tabular}

Source: Goleman (1998) 
From this theoretical grouping Goleman (1998), Boyatzis, Goleman \& Rhee (2000), propose an empirical revision of twenty-one competences, to reduce it to a version of nineteen competences in four groups.

Another list of generic competences is found in the studies of Loren's, Llinàs \& Sabaté (2009), Llorens (2012) and Llorens, Llinàs, Ras \& Chiaramonte (2013). Following the rationalist approach oriented to the worker, these authors start from the approach of twenty competences, to finally establish ten essential generic competences that engineers should acquire to develop their activity in the ICT sector, namely: Ability to work as a team, Customer Orientation, Commitment to learn, Resolutive, Initiative - Proactive, Innovative, Commitment to the company, Ability to search for information, Flexible and Ability to communicate.

In this research, competencies are formalized by adapting them to the microentrepreneur through the elaboration of a list of competencies by groups that serves as a starting point for the consultation of experts and to be able to analyze some proposals regarding how competencies allow the improvement of performance and the study of microentrepreneurs in depressed environments, taking into account the literature review, and specially the studies of Golleman (1998), Sandberg (2000), Boyatzis, Goleman \& Rhee (2000), Llorens, Llinàs \& Sabaté (2009), Llorens, Llinàs, Ras \& Chiaramonte (2013), among others.

\section{Methodology}

While this documentary research tries to contribute knowledge about those competences and the effect that a competence model can have on the performance of microentrepreneurs in depressed environments. The types of documentary research in which the work is methodologically supported are: study of theoretical development, and critical review of the state of knowledge. Documentary research is a process based on the search, retrieval, analysis, critique and interpretation of secondary data, that is, those data obtained and registered by other researchers in documentary sources (Arias, 2012). Its purpose is to contribute by expanding and deepening the knowledge of a specific topic. The originality of the study is reflected in the approach, criteria, conceptualizations, reflections, conclusions, recommendations, and in general, in the author's thinking (UPEL, 2016). On the other hand, the studies of theoretical development, are focused on the presentation of new theories, conceptualizations or original interpretive models, from the critical analysis of empirical information and existing theories; while critical reviews of the state of knowledge integrate, organize, and evaluate existing theoretical and empirical information on a problem, focusing either on the progress of current research and possible ways of solving it, on analysis and internal consistency and externalization of theories and conceptualizations to point out their failures or demonstrate the superiority of some over others, or both.

On the other hand, the validation of the model was carried out with the support of a panel of experts; (Robles \& Rojas, 2015), and its use is accepted in studies aimed at finding consensus on some problem or phenomenon based on the opinion of the experts (Del Rincón \& Arnal, 1995). As evidenced in the extensive literature with applications of this technique, who point out that it is an effective tool to obtain industry opinion on the competence of graduates (Abdul, Mohd \& Azimin, 2016); as an evaluation strategy presents a series of advantages (Cabero \& Llorente, 2013); among other positive aspects. 
In addition to serving as support for the theoretical framework of this research, the review of the state of knowledge allowed the construction of the inventory of questions that would form the scale. Using search engines such as Google Scholar, Science Direct, Scopus and WoS; and descriptors such as "Competences", "Microenterprises" and "Depressed Environments", and their equivalents in English, the main primary sources were selected, where key competences presented in Table 7 were identified and validated with the support of a panel of experts.

In Planning the Expert Criterion, it was based on the initial conception of the problem and the selection of the experts as fundamental steps for the application of the criterion. The experts were selected first, considering the years of experience linked to the microenterprise sector, and according to their wide knowledge of the micro-enterprise, according to the prestige generated by activities related to microenterprise; recognition in institutions and associations linked to micro entrepreneurs; secondly, to be immersed in business as an official or as a teacher with expertise in the subject; and third, to be predisposed to participate in validation, its capability for analysis and logical thinking, its collectivist spirit and self-criticism.

The process consists in the survey of experts, selecting 10 experts in the province of Guayas, 4 in the Province of Los Ríos, 3 in the province of Bolivar and 3 in the province of Santa Elena, according to the number of inhabitants each province that make up the region 5 has.

From an inventory of competences resulting from the literature review, they were classified considering the participation percentages greater than $50 \%$ determined by the criteria of the experts interviewed. That is, competences that did not reach half $(50 \%)$, minimum participation, are not considered for the proposed competency model.

\section{Results}

As a result of the review of the state of knowledge, the inventory of key competences for microentrepreneurs in depressed environments was constructed, shown in Table 7, based on the grouping of competences in emotional intelligence, ECI - Emotional Competence Inventory from the work of Boyatzis (1982), Goleman (1998), and the versions of (Boyatzis, Goleman \& Rhee, 2000), a model of managerial competencies that have been regularly used and recommended by several authors (Manxhari, Veliu \& Jashari, 2017; Veliu \& Manxhari, 2017).

Although there are many initiatives to identify competencies (e.g. Abdul, et al., 2016, Sarwoko, Surachman, Armanu \& Hadiwidjojo, 2013, Cobo, 2012; Medina, Delgado \& Lavado, 2012), one of the most prominent in the literature is the proposal of Goleman (1998), which were later reviewed by the same authors (Boyatzis, Goleman \& Rhee, 2000; Boyatzis, 2009) and applied by Halim, Salem \& Hassan (2015), Suifan, Abdallah \& Sweis (2015), among others.

The inventory of competences detailed in Table 7 is the starting point for the construction of the model of competences for microentrepreneurs in depressed environments and whose structure comprises the grouping of competencies according to the 5 large groups in which they are distributed according to the application area. 
Table 2

Competency Inventory for Microentrepreneurs in depressed environments

\begin{tabular}{|c|c|}
\hline Group & Competence \\
\hline $\begin{array}{l}\text { Self-awareness } \\
\text { (11) } \\
\text { (4) }\end{array}$ & $\begin{array}{l}\text { Emotional Awareness - Self-evaluation - Self-Confidence - } \\
\text { Organizational Mentality - Heterogeneity - Homogeneity - } \\
\text { Cultural Awareness - Ability to Absorb - Self-efficacy - } \\
\text { Entrepreneurship - Availability to change }\end{array}$ \\
\hline $\begin{array}{l}\text { Self-regulation } \\
\text { (14) } \\
\text { (4) }\end{array}$ & $\begin{array}{l}\text { Emotional Self-control }- \text { Reliability }- \text { Diligence }- \\
\text { Adaptability }- \text { Innovation }- \text { Internationalization }- \\
\text { Organizational Implementation - Global Vision - Process } \\
\text { Design - Benchmarking - Planning }- \text { Pragmatism - } \\
\text { Independence - Risk Taking }\end{array}$ \\
\hline $\begin{array}{l}\text { Motivation } \\
\text { (9) } \\
\text { (7) }\end{array}$ & $\begin{array}{l}\text { Achievement }- \text { Commitment }- \text { Initiative }- \text { Optimism - } \\
\text { Organizational Learning - Overcoming Obstacles - Altruism } \\
\text { - Self Learning - Cognitive Ability }\end{array}$ \\
\hline $\begin{array}{l}\text { Empathy } \\
\text { (13) } \\
\text { (6) }\end{array}$ & $\begin{array}{l}\text { Development of Others - Understanding Others - Service } \\
\text { Orientation - Diversity of Use - Political Awareness - } \\
\text { Intermediation - Proactive - Openness to Dialogue - } \\
\text { Visionary - Decision Making - Negotiation - Tolerance - } \\
\text { Observer }\end{array}$ \\
\hline $\begin{array}{l}\text { Social Ability } \\
\text { (15) } \\
\text { (6) }\end{array}$ & $\begin{array}{l}\text { Influence - Communication - Conflict Management - } \\
\text { Leadership - Change Catalyst - Strengthening ties - } \\
\text { Collaboration and cooperation - Teamwork - Transformation } \\
\text { - Associativity - Problem Perception - Opportunism - } \\
\text { Information gathering - Artistic skills - Transfer of knowledge }\end{array}$ \\
\hline
\end{tabular}

Fuente: Self made

The elaboration of the proposal of the competence model is also based on the list selected by the experts with participation greater than or equal to $50 \%$, Table 8 .

Table 8

List of competencies that are most applied by microentrepreneurs

\begin{tabular}{lclc}
\hline Competences & Percentage & Competences & Percentage \\
\hline Commitment & $80 \%$ & Organizational Mentality & $55 \%$ \\
Initiative & $75 \%$ & Availability to Change & $55 \%$ \\
Collaboration and cooperation & $75 \%$ & Reliability & $55 \%$ \\
Innovation & $70 \%$ & Independence & $55 \%$ \\
Self-Learning & $70 \%$ & Cognitive Ability & $55 \%$ \\
Optimism & $65 \%$ & Service Orientation & $55 \%$ \\
Proactive & $65 \%$ & Achievement & $50 \%$ \\
Negotiation & $65 \%$ & Overcoming Obstacles & $50 \%$ \\
Entrepreneurship & $60 \%$ & Intermediation & $50 \%$ \\
Adaptability & $60 \%$ & Observer & $50 \%$ \\
Openness to dialogue & $60 \%$ & Communication & $50 \%$ \\
Teamwork & $60 \%$ & Leadership & $50 \%$ \\
Problem Perception & $60 \%$ & Opportunism & $50 \%$ \\
Self-confidence & $55 \%$ & & \\
\hline
\end{tabular}

Source: Self made 
Areas of action of the microentrepreneur are established, considering the areas of literature review. (See Table 9)

Table 3

Areas and Extents in the literature review on competences

\begin{tabular}{ll}
\hline Research Area & Microentrepreneur Extent \\
\hline Business economics & \\
$\begin{array}{l}\text { Public Administration } \\
\text { Operations Research Management Science }\end{array}$ & BUSINESS (Organizational) \\
Innovate & \\
\hline $\begin{array}{l}\text { Engineering Education Educational } \\
\text { Academic Research International }\end{array}$ & EDUCATIVE (Staff) \\
Journal of Pedagogy & \\
Journal of ICT in Education & SOCIAL (Environment) \\
\hline Social Sciences Other Topics &
\end{tabular}

With the application of the described elements, the competences are organized and distributed according to the performance areas of the microentrepreneur, according to their needs and the practical application they can perform. The microentrepreneur must carry out a previous analysis of his / her skills so that he / she can identify with the competences that are distributed in the three performance areas, namely: Entrepreneurial (organizational), Educational (Staff) and Social (Environment). As shown in Table 10.

Table 4

Proposed competency model for microentrepreneurs in depressed environments

\begin{tabular}{|c|c|c|c|}
\hline \multirow{2}{*}{$\begin{array}{c}\text { Group of } \\
\text { Competences }\end{array}$} & \multicolumn{3}{|c|}{ Performance Areas } \\
\hline & Business & Educative & Social \\
\hline $\begin{array}{l}\text { Self-management } \\
(8)\end{array}$ & $\begin{array}{l}\text {-Organizational } \\
\text { Mentality } \\
\text {-Entrepreneurship } \\
\text {-Innovation }\end{array}$ & $\begin{array}{l}\text {-Self confidence } \\
\text {-Adaptability } \\
\text {-Independence }\end{array}$ & $\begin{array}{l}\text {-Availability to } \\
\text { change } \\
\text {-Reliability }\end{array}$ \\
\hline $\begin{array}{c}\text { Motivation } \\
\text { (7) }\end{array}$ & -Initiative & $\begin{array}{l}\text {-Commitment } \\
\text { - Self-learning } \\
\text {-Optimism } \\
\text { - Cognitive ability }\end{array}$ & $\begin{array}{l}\text {-Achievement } \\
\text {-Overcoming } \\
\text { Obstacles }\end{array}$ \\
\hline $\begin{array}{c}\text { Empathy } \\
\text { (6) }\end{array}$ & $\begin{array}{l}\text {-Intermediation } \\
\text {-Negotiation }\end{array}$ & $\begin{array}{l}\text { - Proactive } \\
\text { - Observer }\end{array}$ & $\begin{array}{l}\text {-Service } \\
\text { Orientation } \\
\text { - Openness to } \\
\text { dialogue }\end{array}$ \\
\hline $\begin{array}{c}\text { Social Ability } \\
\text { (6) }\end{array}$ & $\begin{array}{l}\text {-Teamwork } \\
\text {-Problem } \\
\text { Perception }\end{array}$ & $\begin{array}{l}\text {-Leadership } \\
\text {-Opportunism }\end{array}$ & $\begin{array}{l}\text {-Communication } \\
\text {-Collaboration } \\
\text { and cooperation }\end{array}$ \\
\hline
\end{tabular}




\section{Discussion}

As Boyatzis, Goleman \& Rhee (2000) point out, groups (or clusters) within a competence model must be related in some way and not just a list: They can be parts of a whole and complement each other in functional behavior; they may be alternative manifestations, may be compensatory or may be antagonistic. Thus, the criterion for the proposed model was based on the grouping of Goleman (1998), Boyatzis et. al. (2000) and its theoretical basis and empirical validation.

Competences are considered as a specific set of attributes, starting with the workplace (Fine, 1988), where the internal and external constraints, the environments and the relationships that must do with the work or occupation fit in (Boyatzis, 1982 and Fogg, 1999). Given these assertions, the mixed rationalist approach of Sandberg (2000) is the one that best adapts to the competence model for microentrepreneurs in depressed environments, as the selected competences are applicable to both the company and the microentrepreneur, and in both cases the ultimate objective is to improve its performance and its business structure.

The selected list of competences was elaborated based on the experience and knowledge of the microentrepreneur experts, both in their personal and professional environment, considering also the interaction that they have maintained for years, thanks to the working relationships. This list, further structured by the competences of Boyatzis, Goleman \& Reed (2000), becomes the main input for the elaboration of the competence model that is directed to the microentrepreneur as a guiding instrument that leads in an organized way the development of their administration.

For Boyatzis (1982), three elements enable people to develop specific actions or effective behaviors: competences, job demands and the context of an organization. These elements form the basis of the proposed competence model: the competences that arise from the literature review and the expert opinion; the microentrepreneurs employment needs for their subsistence and the context corresponding to the depressed environments in which they carry out their productive activities.

The more traditional approaches are context-based, but a competence-based model is more broadly linked to the organizational context (Hayton \& Kelley, 2006). If it is also considered that the size of the microenterprise reaches $90.17 \%$ in relation to the total of the business structure of Ecuador, it is necessary to adapt a competence model to the microentrepreneur's environment, especially those who develop their activities in depressed areas, as a strategic tool that supports the delineation of actions aimed at improving its business organization.

According to Sandberg (2000), worker-oriented approaches define competences as a set of individual attributes that shape people's behavior and performance, thus, conceptual and practical knowledge of a competence model helps the microentrepreneur to have a positive and proactive vision of its application, and consider that the model is influential in their work performance and in the organization of their company.

The most valued competences according to the experts were Commitment (80\%), Initiative (75\%), Collaboration and cooperation (75\%), Innovation (70\%) and Selflearning (70\%).

The commitment, which Goleman (1998) includes in the self-motivation group and was excluded in later work (Boyatzis et al., 2000), is presented by Llorens et al (2009, 2012, 
2013) in two modalities. One at a personal level: commitment to learning; and another at organizational level: commitment to the organization, which is a key competence for the microentrepreneur of the repressed environment of Ecuador's Region 5, since it allows the connection of other competences, and guarantees the success of any development initiative of the region's human capital.

Along with commitment, in Motivation, defined as the group of competences characterized by the "passion to work for reasons that go beyond money or state ... propensity to pursue goals with energy and persistence" (Goleman, 1998), self-learning is presented, which forms the motor of the group, that gives this educational field to this area of the microentrepreneur. In this group optimism, cognitive ability, achievement and overcoming obstacles are added, the latter two, aligned with the social interaction of the microentrepreneur.

Cooperation and collaboration, is another of the experts' greater appreciation competences, together with the microentrepreneur's social field communication, is included within the group of Social Skills, defined as those competences characterized by " the ability of managing relationships and networking. The ability to find common ground and make a connection "(Goleman, 1998). Included in this group are teamwork and the perception of business problems and leadership and opportunism in the personal sphere. This group highlights leadership, an interesting area in the field of organizational behavior, in which new studies are constantly emerging (Guiana, Amu \& Kalu, 2015). The Empathy group, characterized by those competences that support "the ability to understand the emotional makeup of other people and the ability to treat people according to their emotional reactions" (Goleman, 1998), includes intermediation and negotiation in the business environment, proactivity and observation in the personal sphere, and service orientation and openness to dialogue in the social environment.

One of the differences of this competence model for microentrepreneurs in proposed depressed environments is presented in the self-management group, which brings together the competences that Goleman (1998) and Boyatzis et al (2000) present in two groups, one of self-awareness and another one of self-regulation. This group is reduced to eight key competences: organizational mentality, entrepreneurial entrepreneurship, entrepreneurial innovation, self-confidence, personal adaptability, independence in the personal sphere, availability to change, and reliability in the social environment.

It is noteworthy that within the twenty-seven-competence group, the ones with the least value (50\%) are achievement, overcoming obstacles, observation, communication, leadership and opportunism, which are most of competences belonging to the business and social field, without which, Ecuador's region 5 microentrepreneur, as a depressed environment, would not perform well.

More critical is the fact that the global vision, internationalization, benchmarking, and other key competences in this globalization phenomenon, on the one hand, are not valued for this environment; and on the other, planning, process development, pragmatism, information gathering, among others, that could characterize an operative microentrepreneur.

As for the model of Llorent et al (2009; 2013), more coincidences are presented, including the ability to work as a team, Service orientation to the client, Commitment to learn and with the company, Initiative - Proactive, Innovative, Communication Capability. 
It is necessary to deepen into empirical validation and reliability in future research, including techniques such as the Delphi method and statistical methods.

\section{CONCLUSIONS}

In this study, a documentary research has been carried out based on a critical review of the state of knowledge in Competence Models, specifically oriented to the microenterprise sector and depressed environments, based on empirical Ecuador's region 5. The study results in a model of competences for microentrepreneurs in depressed environments that identifies 62 competences, which was taken as the basis for an expert consultation. The experts prioritized 27 competences in four (4) dimensions: Selfmanagement, Motivation, Empathy and Social Abilities; and in three areas: business (organizational), educational (personal) and social (environment).

The experts' assessments prioritize the Motivation dimension, highlighting the commitment, initiative and self-learning competences, which could well guarantee the success of any microentrepreneurs' development initiative in this depressed environment. However, the fact of not including competences such as global vision, internationalization, benchmarking, among others, key in this globalized context, is a weakness in the face of foreign investment opportunities. In addition, competencies such as planning, process development, pragmatism and information gathering, of an operational component, distance it from an operational profile required by the depressed environments microentrepreneur.

As implications for future research, it is proposed to use the Delphi method to make better use of information by the panel of experts, and to support qualitative aspects with a quantitative approach.

\section{References}

Abdul, R.; Mohd, N. \& Azimin, N. (2016). Creating a framework for hospitality competencies to fulfill the industry's need. Academic Research International, 7(4), 229236.

Aguilar Barceló, J., Mungaray Lagarda, A. y Ramírez Angulo, N. (2009). “La naturaleza de los determinantes del éxito microempresarial", 4to Congreso internacional sobre las micro, pequeñas y medianas empresas del siglo XXI. Málaga: Grupo Eumed.net.

Aguilar-Barceló, J. G., Texis-Flores, M., \& Ramírez-Angulo, N. (2011). Conformación de la expectativa de formalización de la microempresa marginada en México. Innovar, 21 (41), 63-76.

Areyuna, A. (2010). "Modelo de Competencias para la Innovación Tecnológica” (Tesis doctoral). Universidad Politécnica de Cataluña. España.

Arias, F. (2012). El proyecto de investigación. Introducción a la metodología científica, 6ta edición. Caracas: Episteme.

Banco Mundial (1998). “Política Económica”. Notas Prem., Número 1. USA.

Banco Mundial (2009). "Reshaping Economic Geography in Latin America and the Caribbean". A Companion Volume to the 2009 World Development Report. Washington. 
Baron, R. A., \& Markman, G. D. (2003). Beyond social capital: The role of entrepreneurs' social competence in their financial success. Journal of Business Venturing, 18(1), 4160 .

Beato, P. \& Poli, F. (2008). Las cadenas de valor en las grandes empresas: problemas y propuestas, p. 13-28. En "PYMES: visión estratégica para el desarrollo económico y social”, Leone, A. (Coord.). Venezuela: SELA/AECID.

Bezpalov, V. V., Lochan, S. A., \& Sorokina, N. Y. (2016). Modernization of management of the regional economy as an instrument for solving tasks related to import substitution. Journal of Internet Banking and Commerce, 21(S6), 1-12.

Boyatzis, R. E., Goleman, D., \& Rhee, K. (2000). Clustering competence in emotional intelligence: Insights from the Emotional Competence Inventory (ECI). Handbook of emotional intelligence, 343-362.

Boyatzis, R.E. (1982). The competent manager: A model for effective performance. New York: John Wiley and Sons.

Boyatzis, R. (2009). Competencies as a behavioral approach to emotional intelligence. Journal of Management Development, 28(9), 749-770.

Cabero, J. \& Llorente, M. (2013). La Aplicación del Juicio de Experto como Técnica de Evaluación de las Tecnologías de la Información y Comunicación (TIC). Revista de Tecnología de Información y Comunicación en Educación, 7(2), 11-22.

Campion, M. A., Fink, A. A., Ruggeberg, B. J., Carr, L., Phillips, G. M., \& Odman, R. B. (2011). Doing competencies well: Best practices in competency modeling. Personnel Psychology, 64(1), 225-262.

Cancino, C. A., Coronado, F., \& Farias, A. (2012). Background and Results of Dynamic Enterprises in Chile: Five Success Cases. Innovar, 22 (43), 19-32.

Capello, R. (2006). La Economía Regional tras cincuenta años: Desarrollos teóricos recientes y desafíos futuros/Regional Economics in its Fifties: Recent Theoretical Directions and Future Challenges. Investigaciones regionales, (9), 169-192.

Chwolka, A., \& Raith, M. G. (2012). The value of business planning before start-up: A decision-theoretical perspective. Journal of Business Venturing, 27(3), 385-399.

Cobo, C. (2012). Competencias para empresarios emprendedores: contexto europeo. Bruselas: OIT/CINTERFOR.

Dall'Alba, G., \& Sandberg, J. (1996). Educating for competence in professional practice. Instructional science, 24(6), 411-437.

Deciusa, J. \& Schapera, N. (2017). The Competence Management Tool (CMT) - A new instrument to manage competences in small and medium-sized manufacturing enterprises. Procedia Manufacturing, 9, 376-383.

Del Rincón, D., Arnal, J., Latorre, A., \& Sans, A. (1995). Técnicas de investigación en ciencias sociales. Dykinson. Madrid.

Elosúa M. (1999). Diccionario LID de Empresa y Economía. Madrid: LID Editorial Empresarial, S.L.

Estay, C.; Durrieu, F. \& Akhter, M. (2013). Entrepreneurship: From motivation to startup. Journal of International Entrepreneurship, 11(3), 243-267. 
Fernández, G. \& Guadaño, J. (2005). El empresario individual: situación actual y propuestas de actuación futuras. CIRIEC-España, Revista de economía pública, social y cooperativa, (52), 201-217.

Fine, G. A. (1988). Friends, impression management, and preadolescent behavior. Childhood socialization, 209-233.

Fogg, C. D. (1999). Implementing your strategic plan: How to turn "intent" into effective action for sustainable change. New York: American Management Association.

Gohmann, S. F. \& Fernandez, J. M. (2014). Proprietorship and unemployment in the United States. Journal of Business Venturing, 29(2), 289-309.

González, J., \& Wagenaar, R. (Eds.). (2003). Tuning educational structures in Europe. Final report. Phase one. Bilbao: University of Deusto.

Goleman, D. (1998). What Makes a Leader? Harvard Business Review, 76(6), 93-102.

Green, P. (1999). Building robust competencies: Linking human resource systems to organizational strategies. Jossey-Bass Inc Pub.

Halim, H.; Salem, K. \& Hassan, O. (2015). Assessing Emotional Intelligence Competencies in Public Sector Petroleum Companies in Egypt. Journal of US-China Public Administration, 12(4), 290-303.

Hay Group McClelland Center for Research and Innovation (2005). Emotional Competence Inventory: Technical Manual. USA: McClelland Center for Research and Innovation.

Hayton, J. C., \& Kelley, D. J. (2006). A competency-based framework for promoting corporate entrepreneurship. Human Resource Management, 45(3), 407-427.

Hernández, S. B. (2009). El papel de las microempresas en el desarrollo económico regional: las redes de cooperación empresarial en España. REVESCO: Revista de estudios cooperativos, (99), 31-59.

Iduarte, J. y Zarza, M. (2005). "La administración del diseño en micro, pequeñas y medianas empresas mexicanas (Conferencia)". Consultado en http://www.dis.uia.mx/conference/2005/HTMsPDFs/AdmondelDisenoenEm presas.pdf.

Instituto Ecuatoriano de Estadísticas y Censos (INEC). 2016. Reporte de pobreza y desigualdad.

Instituto Nacional de Estadísticas y Censos, INEC (2014). Directorio de Empresas y Establecimientos. Consultado en http://www.ecuadorencifras.gob.ec//documentos/webinec/Estadisticas_Economicas/DirectorioEmpresas/Empresas_2014/Principales_Resulta dos_DIEE_2014.pdf

Karlsson, T., \& Honig, B. (2009). Judging a business by its cover: An institutional perspective on new ventures and the business plan. Journal of Business Venturing, 24, $27-45$.

Latham, J., Jones, R., \& Betta, M. (2009). 18. "Critical social entrepreneurship-an alternative discourse analysis". Critical management studies at work: Negotiating tensions between theory and practice, 285 .

Llorens, A. (2012). "Propuesta metodológica para la determinación y el aprendizaje de las competencias genéricas clave del/la ingeniero/a TIC y percepción diferencial del Mercado entre el grado y el postgrado o master" (Tesis Doctoral). Programa de Doctorado 
en Administración y Dirección de Empresas. Universitat Politécnica de Catalunya. España.

Llorens, A., Llinàs-Audet, X., Ras, A. \& L. Chiaramonte, L. (2013). ICT skills gap facing Bologna process: Industry expectations versus university preparation in Spain. Computer Applications in Engineering Education, 21(2), 256-264. DOI: http://dx.doi.org/10.1002/cae.20467

Llorens-Garcia, A., Llinas-Audet, X., \& Sabate, F. (2009). Professional and interpersonal skills for ICT specialists. IT professional, 11(6), 23-30. DOI: http://dx.doi.org/10.1109/MITP.2009.132

Lucia, A. D., \& Lepsinger, R. (1999). “Art \& Science of Competency Models”. San Francisco, CA: Jossey-Bass.

Mac-Clure, O. (2001). Las microempresas. ¿Una solución a los problemas de empleo?. Proposiciones, 32, 158-169.

Makhbul, Z. M., \& Hasun, F. M. (2011). Entrepreneurial success: an exploratory study among entrepreneurs. International Journal of Business and Management, 6(1), 116-125.

McClelland, D.C. (1973), Testing for competence rather than intelligence, American Psychologist, 28(1), 1-40.

Man, T. W. Y., Lau, T., \& Chan, K. F. (2002). The competitiveness of small and medium enterprises. A conceptualization with focus on entrepreneurial competencies. Journal of Business Venturing, 17, 123-142.

Manxhari, M.; Veliu, L. \& Jashari, J. (2017). Developing models of managerial competencies of managers: a review. International Journal of Economics, Commerce and Management, 5(4), 186-200.

Markman, G. D., \& Baron, R. A. (2003). Person-entrepreneurship fit: Why some people are more successful than others. Human Resource Management Review, 13, 281-301.

Medina, A.; Delgado, A. \& Lavado, P. (2012). Fundamentos de un sistema de gestión humana por competencias para soportar la estrategia organizacional en una pyme del sector de la industria de las artes gráficas en Cali (Colombia). Estudios gerenciales, 28(122), 121-138.

Mel'nikova, L. V. (2015). Space-neutral and place-based regional policies: The problem of choice. Regional Research of Russia, 5(1), 1-9.

Ministerio Coordinador de Producción, Empleo y Competitividad (2017). Zonas deprimidas. Tomado de http://www.produccion.gob.ec/zonas-deprimidas/

Mirabile, R. J. (1997). Everything you wanted to know about competency modeling. Training \& Development, 51(8), 73-78.

Montoya, A. M. H., (2015). La lúdica en la formación de empresarios, convierte al docente en conductor del proceso de enseñanza-aprendizaje. Desarrollo, Innovación y Cultura Empresarial, 64.

Mulder, M., Lans, T., Verstegen, J., Biemans, H., \& Meijer, Y. (2007). Competence development of entrepreneurs in innovative horticulture. Journal of Workplace Learning, $19,32-44$.

Mungaray, A. (1997). Organización industrial de redes de subcontratación para pequeñas empresas en la frontera norte de México. México: Nafin, p. 18- 41. 
Mungaray, A. \& Ramírez, M. (2007). Capital humano y productividad en microempresas. Investigación Económica, 66(260), 81-115.

Mungaray, A., Ramírez, N. \& Texis M. (2005). Estructura de mercado y maximización de beneficios en las microempresas, Comercio Exterior, 55(4), 316-321.

Mungaray, A.; Feitó, D. \& Texis, M. (2016). Factors associated with learning management in Mexican micro-entrepreneurs. Estudios Gerenciales, 32, 381-386.

Neef, D. (1998). “The knowledge economy: An introduction”. The Knowledge Economy. Butterworth-Heinemann. Boston.

OECD (2009). How Regions Grow: Organization for Economic Growth and Development. Paris: OECD.

Perrenoud, P. (2004). Diez nuevas competencias para enseñar: invitación al viaje (Vol. 196). Graó.

Ramírez-Urquidy, M., Mungaray, A., \& Guzmán Gastelum, N. Z. (2009). Restricciones de liquidez en microempresas y la importancia del financiamiento informal en Baja California. Región y sociedad, 21(44), 71-90.

Ramirez-Urquidy M. \& Mungaray, A. (2016). The role of education and learning by experience in the performance of Microenterprises. Procedia - Social and Behavioral Sciences, 228, 523-528.

Rivero, F., Ávila, M.T., \& Quintana, L. (2016). La promoción integral de la microempresa; Guía de mercadeo para las organizaciones promotoras. Madrid: Popular.

Robles, P. \& Rojas, M. (2015). La validación por juicio de expertos: dos investigaciones cualitativas en Lingüística aplicada. Revista Nebrija de Lingüística Aplicada a la Enseñanza de Lenguas, 18, 103-118.

Rodríguez, D., Patel, R., Bright, A., Gregory, D., \& Gowing, M. K. (2002). Developing competency models to promote integrated human resource practices. Human Resource Management, 41(3), 309-324.

Ruiz, C., Hernández, B., \& Hernández-Fernaud, E. (2004). Estrategias de afrontamiento al estrés producido por el ruido percibido dentro de la vivienda. Medio ambiente y comportamiento humano, 5(1y2), 133-152.

Sachs, J. D., \& Warner, A. M. (2001). The curse of natural resources. European economic review, 45(4), 827-838.

Sandberg, J. (2000). Understanding human competence at work: an interpretative approach. Academy of management journal, 43(1), 9-25.

Sarwoko, E.; Surachman, Armanu \& Hadiwidjojo, D. (2013). Entrepreneurial Characteristics and Competency as Determinants of Business Performance in SMEs. Journal of Business and Management, 7(3), 31-38.

Shippmann, J. S., Ash, R. A., Batjtsta, M., Carr, L., Eyde, L. D., Hesketh, B., ... \& Sanchez, J. I. (2000). The practice of competency modeling. Personnel psychology, 53(3), 703-740.

Shane, S., \& Venkataraman, S. (2000). The promise of entrepreneurshipas a field of research. Academy of Management Review, (25), 217-226.

Singh, V. \& Srivastava, S. (2014). Understanding Competencies and Competency Modeling - A Literature Survey. Journal of Business and Management, 16(1), 14-22. 
Suifan, T.; Abdallah, A. \& Sweis, R. (2015). The Effect of a Manager"es Emotional Intelligence on Employeese Work Outcomes in the Insurance Industry in Jordan. International Business Research, 8(9), 67-82.

Tehseen, S. \& Ramayah, T. (2015). Entrepreneurial Competencies and SMEs Business Success: The Contingent Role of External Integration. Mediterranean Journal of Social Sciences, 6(1), 50-61.

Texis, M.; Ramírez, M. \& Aguilar, J. (2016). Microempresas de base social y sus posibilidades de supervivencia. Contaduría y Administración, 61, 551-567.

Ugoani, J.; Amu, C. \& Kalu, E. (2015). Dimensions of emotional intelligence and transformational leadership: a correlation analysis. Independent Journal of Management \& Production, 6(2), 563-584. DOI: http://dx.doi.org/10.14807/ijmp.v6i2.278

UPEL-Universidad Pedagógica Experimental Libertador (2016). Manual de Trabajos de Grado de Especialización y Maestría y Tesis Doctorales, 5ta edición. Caracas: FEDUPEL.

Urrego, R. R. (1998). El desarrollo del conocimiento y el manejo de las organizaciones: a propósito de la discusión sobre el taylorismo. Innovar, (11), 26-38.

Veliu, L. \& Manxhari, M. (2017). The impact of managerial competencies on business performance: SME's in Kosovo. Vadyba Journal of Management, 1(30), 59-65.

Volery, T., Mueller, S., \& von Siemens, B. (2015). Entrepreneur ambidexterity: A study of entrepreneur behaviours and competencies in growth-oriented small and medium-sized enterprises. International Small Business Journal, 33(2), 109-129.

Wagener, S., Gorgievski, M., \& Rijsdijk, S. (2010). Businessman or host? Individual differences between entrepreneurs and small business owners in the hospitality industry. The Service Industries Journal, 30(9), 1513-1527.

Williamson, J. G. (1965). Regional inequality and the process of national development: a description of the patterns. Economic development and cultural change, 13(4, Part 2), $1-84$.

Winterton, J., Delamare-Le Deist, F., \& Stringfellow, E. (2006). "Typology of knowledge, skills and competences: clarification of the concept and prototype”. Luxembourg: Office for Official Publications of the European Communities.

Woodruffe, C. (1990). Assessment centers: Identifying and developing competence. London: Institute of Personnel Management.

Worlikar, M. \& Aggrawal, A. (2017). Review Study of Competency Mapping in the Organisations. Journal of Business and Management, 72-76.

Zalina, I.; Firdaus, A. \& Azman, I. (2016). International Business Competence and Small and Medium Enterprises. Procedia - Social and Behavioral Sciences, 224, 393-400. 